\title{
Microcredit, money transfers, women, and the Cameroon diaspora
}

\author{
Shirley Ardener \\ Institute of Social and Cultural Anthropology, International Gender Studies \\ University of Oxford, United Kingdom
}

\begin{abstract}
The paper introduces the topic of Rotating Savings and Credit Associations (ROSCAs) and several other forms of microcredit institutions, variations of which are found in most communities around the world, and considers the impact on them of the current financial crisis. For many women and men, poor and wealthy alike, these institutions have been economic and social lifelines. Among many African peoples, they provide the main source of rural and urban credit, both for sustainable living and entrepreneurial endeavour. This paper draws on the experience of contemporary Cameroonians, including those in the diaspora, in particular that of Dr Bridget Teboh. Social anthropologists have espoused ROSCAs for many decades. This paper cites the increasing attention such institutions now get from governments, NGOs, bankers and economists, and considers the impact of the current worldwide financial crisis on the behaviour of those who save in them.
\end{abstract}

Key words: microfinance, tontines, ROSCAs

Microfinance in West Africa has been a recurrent theme among my diversified academic interests, being the topic of my first and this, my most recent paper. As soon as I graduated, I went straight out to West Africa with my husband to live among the Igbo of Nigeria. I had read some economics as an undergraduate, and soon after arriving in the village, I wrote my first paper for a conference at Ibadan on the savings clubs which were so critical to village life (Ardener 1953). A few years later, on returning to Oxford, I sought out as much comparative material as I could find and wrote an analytical paper (Ardener 1964; reprinted in Ardener 1995). My interests then turned to other topics for some years until I convened a workshop, the results of which were published in 1995 as Money-GoRounds; the Importance of ROSCAs for Women, which I edited with Sandra Burman.

ROSCAs are associations in which members regularly contribute to a fund that is given in whole or in part to each contributor in turn. This simple formula - and in particular its rotating feature - has made the ROSCA a surprisingly enduring and flexible instrument, which has helped millions of the poor - both women and men. The usage "ROSCA" is a scholarly, or literary, term, not one normally used by those who make use of these institutions, who have their own, various, names for them. It identifies one form of 
saving institution, with features as defined hereabove. Today, as before, for many developing countries microcredit is the main source of rural capital - far surpassing the sums available to the general public from banks, NGOs and international aid programmes. We also find ROSCAs used by the well-off, even by those in high political circles, both for their economic and social benefits.

It sounds simple. Let's say that each month for a year, a group meets and each present puts equal amounts of money in a pot. At each meeting, the pot is then given to one of the members, and again for twelve times until all the members have had their turn to receive it. At the end of the cycle it may close, or continue its rotation over again, even many times. There are many variations of this model in real life. Small groups of $12-50$ members are common, but they can be scaled up to many hundreds of members. Dues can range from a handful of rice to cheques valued at hundreds of euros - yielding pots of thousands. Transactions are transparent; if the pot is handed over to a member each time there is no banker.

If everyone puts in the same and each gets out the same, members usually feel they are equal. But do they get the same benefits? No, not exactly. For the early birds to take the pot get credit from those members yet to take. Given this inequality, why is the ROSCA so popular, both among villagers and elites in India and Africa? Indeed, as my colleague Charles Fonchingong noted in 2008, 90\% of the old people he was interviewing in Cameroon belonged to ROSCAs. In much richer Taiwan, $80 \%$ of the people still belong to ROSCAs (Besley and Levinson I993). ROSCAs under the name of "chit funds" (also known by many local names) have long existed on the Indian sub-continent. Some of these were commercially driven. Traditional ROSCAs continue among the Indian Diaspora (see Shaila Srinivasan 1995). ROSCAs are also found in Japan and the USA. I guess there must be many thousands who save in ROSCAs in the UK. No doubt there are many in Belgium. Little regarded when I began, it is not surprising that now anthropologists, economists, bankers and government officials write so much about microfinance.

I have attended a number of ROSCA meetings. One, which took place at the University of Buea in Cameroon, was mainly composed of university lecturers. The meeting was held in a private house. Members were present with their wives and children. The atmosphere was jovial, with a sense of excitement at seeing the handfuls of money building up. Over drinks, people watched the money collected being counted out by two or three of the members - to much banter, teasing accusations and counter accusation, and hilarity. The person to be hosting the next session - and the next to take the pot - was singled out for attention. The order of rotation seemed to be already determined. A delicious buffet and drinks were provided by the family getting the pot.

Cameroon village ROSCAs are similar in principle, though sometimes on a more modest scale. At the other end of the range, in some countries ROSCA meetings may take place in posh hotels or cafés (Ardener, I995, p.ro; Khatib-Chahidi I995, p.246-47).

Before I come to reviewing their overall advantages and disadvantages, let me give you a personal story. In September 2009, when I was putting an early version of this paper together for a meeting of the Oxford Alumni Weekend, by chance I was visited by my 
Cameroon friend Professor Bridget Teboh, a university lecturer at the University of Massachusetts at Dartmouth, USA. Bridget shares my interest in ROSCAs and kindly told me about her own current savings.

Bridget belongs to no fewer than six ROSCAs in the United States and to one ROSCA back in Cameroon. Let us take first the six in the States. All the members come from Cameroon, mostly from Bridget's own ethnic group, the Moghamo. Four of them are open to both men and women, while the other two are women-only.

As for size - three of them have 12 members each, one has 14 members, and another has 15 members, while the biggest has 20 members. In those with more than 12 members, two or more share their monthly payment and their pot (or in Bridget's terms their "pick") when it is their turn to get it. The biggest of her ROSCAs, with 20 members has I5 "picks" - which means that half the members share the cost of their inputs and their pots.

Cameroon ROSCAs often have fancy, sometimes ironical, names, such as "The Modest Sisters" (Niger-Thomas I995, pp. 104-05); Bridget's elite group have dubbed theirs the "Stress Free Group"; another of her ROSCAs is known as the "Girls' Night Out" or the "All Girls' Njanggi" - Njangi being the Cameroon name for a savings club.

As for the members: in one of Bridget's American ROSCAs, all are former fellow undergraduates from the University she attended in Yaounde, four of whom are in Boston, USA, and three are in Cameroon, five being elsewhere. They all send their dues by cheque. In one of Bridget's women-only ROSCAs, all members are former classmates, who entered the same school in 1972, in Mbengwi, Cameroon. This small group is part of a larger association of 50 classmates, which has lasted 37 years - so far! Bridget's other all-women Cameroon group are civil servants and the like, all resident and working in America.

We can see that, through Bridget's American-based ROSCAs, she is in close contact with 123 Cameroonians, plus their families and friends. Some of them she sees monthly, others meet at occasional get-togethers in Washington or Los Angeles. These circles of Cameroon friends within America form an important social network for Bridget. In academic jargon they are part of her "social capital". While most ROSCAs are jolly affairs, with food, drink and general merriment, "social capital" offers much more than that (see Ardener i964 and 1995).

So, how much does this all cost Bridget? Her dues vary from $\$ 50$ to 500 dollars each month. Altogether then she pays (saves) I,300 dollars monthly - a sizable amount from an academic salary.

If this is what Bridget pays in, what has she already got out on credit? By the middle of 2009 when she met me she had already taken one "pick" of \$7,500 and one "pick" of $\$ 2,400$, both of which she sent home to her village in Cameroon so that her mother could refurbish her house, ready for the over-due second burial celebrations of her father who died in 1977 - an important obligation for any family. Bridget also took out 3,000 dollars for an air fare to Europe (to give an academic paper) and for related expenses. The rest she kept to cover her dues till the end of her seven ROSCA cycles. Meanwhile, Bridget 
still has one "pick" of \$600 and one of $\$ 7,500$ in her American-based ROSCAs which she hasn't yet received.

When you think about it, Bridget is a creditor to those members in her six ROSCAs who took their "picks" before her; such lucky members will continue to pay off their debts in membership dues until all the members have received their turns. Now she is indebted to all those who contributed to the picks she has received so far.

So much for her American ROSCAs. There is more: Bridget is sending \$50 each month to her mother in Moghamoland, to pay for 2 "picks" on her behalf to the Moghamo Cultural and Development Association. This has 24 members, some of whom share their dues and picks, and some who, like her, pay twice each meeting towards 2 "picks". Bridget has been fortunate in having received her "picks" already; she has already invested the money in the purchase of land in Cameroon.

The range and scale of Bridget's budgeting surprised me. Even she seemed surprised as she recounted this, and saw the table I had constructed from what she said. Certainly not all of my overseas Cameroon friends maintain such a complicated set of obligations (though they probably all belong to one or more ROSCAs). Why? Not only because it forces them to save. Each saver also helps others to save. Moreover, this is a public activity, through which people can build up a reputation for prudence and reliability. People will do almost anything to maintain their membership.

Indeed, to be unable to join a ROSCA comes close to social exclusion. Membership is not given lightly - it has to be earned. Bridget herself said it was an honour to belong to her groups. Elites who live outside their villages, at home or abroad, continue to send small dues back to their low-cost village ROSCAs, just to prove their solidarity with their kin. They thus affirm their identity as sons and daughters of the soil.

So far we have been talking only of rotating associations where all the savings paid in each month go out each month to one of the members. No banker is needed, thus avoiding the possibility of theft. This feature is very comforting, especially to the poor and uneducated, who are generally risk adverse. As noted, they feel confident because they can see the transparency of the system, especially in the common local, face-to-face, associations.

There are also microcredit clubs which do not rotate. These are sometimes known as ASCRAs (Accumulating Savings and Credit Associations - in which payments vary), or RESCAs (Regular Savings and Credit Associations). Such groups may get help from NGOs which start them off with a float, and which expect loans to be made and repaid. They need a trustworthy, even-handed "banker", and they need good accounting and transparency procedures - which they do not always get. The best work well, but they are more prone than ROSCAs to discontent and even meltdown.

Often ASCRAs and RESCAs omit some of the face-to-face arrangements found in most of the smaller ROSCAs. ASCRAs and RESCAs usually require guarantors who provide sureties (known in Cameroon as "shortees"; Niger-Thomas I995 p.108), since - especially in the larger ones - reputations are not so easily assessed. ASCRAs may rent premises (see the case of Kenya noted below) and they may be able to accumulate bigger 
lump sums loans than ROSCAs. In other words, they begin to approach mini-bankhood. Indeed the accumulated funds may well be deposited in a bank, or with a credit union. Of course, as they become more formalized, they may become more distant, both geographically and in relations between the officers and members. Peer pressure may be encouraged, but usually it is not as intense as in the ROSCAs. Yet they are found useful. As noted, $90 \%$ of the elderly people interviewed by Fonchingong belonged to ROSCAs, but $60 \%$ of them also had money in a credit union (usually run as an ASCRA). Since each member's savings in an ASCRA may vary, their accumulations will not be equal; each ASCRA member's deposit keeps its own accounting identity - unlike the pooled money collected in ROSCAs.

Of course, Cameroonians understand about one-to-one loans. They borrow from their family, money lenders and sometimes from banks. And, of course, members with recent "picks" can be turned to privately for urgent loans. Moreover, it is not uncommon in a ROSCA to ask each member, as they get their "pick", to put a fixed sum into a loan fund. The loan fund, sometimes called the "trouble" fund, can be augmented from fines (such as from those who come late, or otherwise transgress). Any members who are short of their dues, or who otherwise need a small loan, may borrow from this "trouble" fund, if other members agree. In which case, interest, often high, may well be charged. Finally, the money in the fund might be divided up, or spent on festivities, or on other agreed purposes. If the sum in the fund is carried forward to the next cycle, it may build up significantly. It requires a reliable custodian; today this may be someone with a bank account, and possibly a computer.

It will not surprise you to learn that Bridget, besides her 7 ROSCAs, also subscribes to an ASCRA, based in Washington. It has 100 members in the USA, plus 40 in Cameroon who send money. Members pay in variable amounts, from $\$ 200$ to $\$ 300$ (the maximum). The money is banked in the USA. Consultations are currently taking place with their banker for the purchase of property, which is relatively cheap in America at the moment. Because the group has established a history of responsibility, it is likely that a bank loan will be forthcoming, which they plan to repay from accrued rents.

This is a risky business, but there are successful precedents. For example, Nici Nelson (1995, pp. 6I-62) tells in detail how a group of women living in Mathura Valley, then a slum part of Nairobi, started a simple ROSCA in 1970. After some time, members built a small lean-to with a cardboard roof, which after some successful years bore forth an ASCRA. With their accumulated funds the women bought a butcher's shop, and later other property. By the I990s, they had 3 bank accounts and an architect was designing a block of apartments for them.

In Cameroon, members of ROSCAs do not think of their "picks" as loans. Such money does not seem to be credit. Members get their money back sooner or later. It is rightfully theirs. They own it. The difference between the members is seen to be just one of timing.

Some ROSCAs may be dedicated to particular household purchases - for example saucepans, clothing, or house building materials. Members might want to raise the so- 
cial standing of the group, and accordingly may check on how the pots are used. Such dedicated ROSCAs also prevent husbands from getting at their wives' funds.

We noted that while ROSCA members may feel equal, they gain differently - those who take first can be first to buy desired consumables, to travel abroad, or to use the credit to generate income. Small-scale entrepreneurs often raise their working capital this way. It may offer them their first rung on the entrepreneurial ladder. The order of turn taking is therefore critical. Cameroonians usually decide the order in advance - by taking names from a hat, or by seniority of membership, or by repeating or reversing the former order.

In other countries, in Asia in particular, people may employ various sophisticated and sometimes extremely complex processes. This kind of ingenuity has fascinated me since I first became interested in ROSCAs. There is no time to cover all the sophisticated arrangements people have thought up. These mechanisms rebalance the advantages and disadvantages. Some of them are described in Money-Go-Rounds (Ardener 1995 pp.202-204, 210-217) and in other available publications. Apart from taking the order by lot, members may compete, by offering to take a smaller pot; the bidding might be fiercer at the early point in the cycle. Sometimes this system is called a "Dutch auction". Thus, by various methods, those taking early, end up paying more than they get, and those who wait, get more than they put in. The difference may be seen as a form of interest paid by those who take their turns at the beginning of the cycle to those who wait longer.

What may seem strange is that, even when no interest is involved, as is usually the case in Cameroon, many are prepared to wait their turn. Members may like to have unclaimed funds, ring-fenced from daily subsistence demands and those from friends and family, which they can apply for in time of trouble. The order of the turns to take picks can be renegotiated. This valuable form of social security works well - provided members are mutually committed to helping out anyone who has an unexpected illness or death in the family, whose house burns down, or the like. Most face-to-face ROSCAs in Cameroon work this way. Thus, the ROSCA can work like an insurance policy. Many people, like Bridget, therefore belong to several ROSCAs, some of which have already borne fruit while others are waiting to be harvested.

It often astonishes observers that ROSCAs very rarely fail to reach the end of a cycle. One reason is that members may already have mutual moral obligations to each other. Members also have a practical interest in helping each other maintain their dues. If anyone defaults, not only will the creditors yet to get their pots lose them, but also the reputation of the group will be at stake. According to Ian Fowler (personal communication), for this reason the failure of a ROSCA may be played down, especially as (in Cameroon) witchcraft accusations are often involved when they collapse. If a member does default, the others will together make up the deficit from the joint "trouble fund" if necessary. Because collapse of a ROSCA means loss of reputation for all, membership is not offered lightly. It will not be given to known defaulters. As noted, Bridget considered it an honour to join some ROSCAs. Too much depends on one's reputation to lose it. Members wisely join groups where dues match their income. Or, as we have seen, two members some- 
times pair-up, each paying half of each contribution (and getting half the pick) in order not to over-extend themselves, or a member may double his/her contribution and receive two "picks" - thus allowing members to operate together at different levels of contribution. Members often join several small ROSCAs with different dates for dues, to spread the risks. The longer the circle rotates the bigger the trust. Remember, Bridget's school friends have been meeting since 1972 - now more than 37 years. My friend Dr Margaret Niger Thomas' fourteen or so 'Modest Sisters' have been meeting monthly since 1983 . In I99I they were contributing to a monthly lump sum then equivalent to $£_{2}, 800$ (see NigerThomas i995).

ROSCAs are sometimes criticised for being small and unambitious. Yet big ones, with high dues do exist. The largest known to Bridget was in Douala, the Francophone business centre of Cameroon. This had a "pick" worth a little under $£_{5000}$ (at today's exchange rate). She had heard talk of one four times larger. Such high-value Cameroon ROSCAs are mainly based on a small group of "big men", some of whom - if big enough - double their monthly dues and accordingly take two "picks". Ian Fowler suggests (personal communication) that the term microcredit might no longer be appropriate when such sums are involved. In Cameroon, these big ROSCAs are known as tontines d'affaires, in contrast to the more domestic tontines de solidarité (see Rowlands 1995). Cameroon big men lay their money out to each other at a cost, sometimes reached by auction. Rather than have money lying idle and at risk at home, or earning little interest in a bank, such entrepreneurs farm it out through a network of debt relations, gathering moral and actual credit which can be called in, should an opportunity or emergency arise. The blessing of this (as in all ROSCAs) is that such money is always at work.

ROSCAs have existed on the Indian sub-continent long before the introduction of the highly successful microcredit institution founded by Professor Yunus 33 years ago, well-known as the Grameen Bank. The Grameen Bank offers small loans to women, for the purchase of such things as a cow, or a sewing machine perhaps, which they pay back with the profits from surplus milk, or dressmaking. Chit Funds had many local names; some of them were commercially driven.

Formerly banks used to ignore the poor, due to the high administrative costs of small accounts. Bankers also believed the poor to be bad debtors. How the views of bankers and economists have changed! The women in their RoSCAs, Professor Yunus and many other NGOs, have proved these wrong. The Gatsby Trust in Cameroon is an NGO which, in $1985-1989$ and in 1990 , loaned out money to women who already had ROSCA groups. The Trust gave the women training in capacity building, and business techniques. It held local trade fairs. A study in 2002 noted recovery rate for the loans was $97 \%$. Only $35 \%$ of women said that they had more decision-making power due to Gatsby. Husbands and in-laws were sometimes non-cooperative. $83 \%$ said they sought their husband's agreement before they got involved in enterprises. Only $34 \%$ held "bank accounts" separate from their husband's. Only $12 \%$ who got a bank account did so because of Gatsby. The women used their money for consumption, to solve family problems, cover illnesses, meet school fees, rents etc. 
In 1994, I was invited to a meeting at the Brookings Institution in Washington on "Financial Services and the Poor: U.S. and Developing Country Experiences", funded by USAID. The bankers' talk was all about mobilizing the money of the poor, and about transferring the high cost of administering credit onto their shoulders. Interestingly, they hoped that lessons from experiences abroad in providing financial services for the poor might be transferrable to the US home market.

Elsewhere, building societies and bankers in South Africa have been quick to eye the huge sums floating across the urban economic scene through stockvels (one of the local names for a type of ROSCA - see Burman and Lembete, 1995; Verhoef, 1999). In the

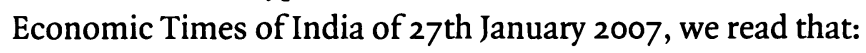

"The banking sector can discover the 'fortune at the base of the pyramid' by using this scheme/policy to provide real financial inclusion for the poor and also [itself] benefit in the process. Till now, banks were looking at these accounts from a purely credit perspective. Instead they should look at this from the point of view of meeting the huge unmet need of the poor for savings. The poor households want to save and, contrary to the common perception, do have the funds to save, but it is not easy for them. Informal mutual savings systems like ... ROSCAs, widespread in Africa, and 'thrift and credit groups' in India demonstrate that poor households save."

In Argentina also, bankers have their eyes on ROSCA money. In February 2009, I was informed by Professor Carlos Velez-Ibanez, who is updating his original monograph on ROSCAs in Mexico, that "There is a bit of an interesting development process in that Nissan, Volkswagen, and other commercial ventures have now incorporated ROSCAs in order to finance the purchase of their automobiles and other companies who specialize in household wares, computers, and other electronic devices like television sets and so on" (Velez-Ibenez, personal communication).

Over the years, various governments have taken an interest in microfinance associations, especially in ASCRAs and large ROSCAs conducted mainly commercially. Japan and India have had special legislation for Kõ and Chit funds for some time. Yet many authorities have hesitated to interfere with ROSCAs, for fear of stifling them or sending them underground. As for the law, Rowlands (I995 p. II5) notes that, in Cameroon:

"The importance of ... debt in the maintaining of business networks is most clearly seen in the astonishing fact that, while bankruptcy proceeding legally exists..., it is rarely taken advantage of by creditors...."

In Cameroon there is a tradition of mutuality, and a desire to maintain harmony, especially since some have fears of witchcraft. Sensibility to the feelings of others avoids the stress on shaming found in some Asian and other contexts. So, in Cameroon, rather than going to court, "People look immediately to the rescheduling of debts through collective bargaining with creditors, and converting the debt into a social resource" 
(Rowlands, op. cit.). Here we come to the all important "social capital" again.

Economists too are lured by ROSCA money. They devise complicated formulae long equations - which, for example, compare the value of allocating by lot or deciding by auction, or by other means (see e.g. Besley, et al., 1993). And every now and then, there is a discussion about introducing intermediary institutions between grassroots ROSCAs and formal financial institutions, attempting to get the best of both worlds. Thus, in November 2008, S. Bai Senghor, the Director of the Microfinance Department of the Central Bank of the Gambia, at a meeting in Tanzania at Africa's Technical Workshop on Innovations in Addressing Rural Finance Challenges in Africa, noted that his Government:

"continues to give due attention to the growth and development of the Microfinance sub-sector as it has been recognized as one of the most effective tools to alleviate poverty...."

Senghor wants to establish financial trusts which can manage or hold funds for microfinance institutions, or act as a link between them and a donor or bank. Such an apex or second-tier institution, he says, should not raise money direct from the public. That could be left to members of ROSCAs, ASCRAs and RESCAs who, consequently, would bear the responsibility of assessing credit-worthiness, and save the financial trust the heavy cost of administering small loans.

Senghor notes that donors, given the scales of the problem of rural financial service delivery, donor policy and institutional support "can no longer neglect the grassroot institutions, but should see them as "the 'bottom-up' spike of a two-pronged approach to extending outreach into rural areas of the Gambia". Like many well-meaning bankers and NGOs, as a member of his government he would like to get his hands on this independent, largely self-sustaining circulation of ROSCA money.

\section{Concluding Remarks}

When I began to take an interest in ROSCAs all those years ago, it was Geertz's idea, from his work in Java in 1960 , published in 1962 , that the ROSCA was an intermediate institution between traditional forms of cooperation and modern formal financial institutions which would fade away as members became more sophisticated. He was right, in so far as many members did acquire skills in handling money, and they came to see the merits in regularity, daily self-denial for long-term gains, in the value of reputation, and trust in legal protection. In effect they began to use banks, insurance companies and the like. The Scots and English once used the, now little-known, terms ménages or diddlum for their savings clubs through which women bought blankets and other household goods. Such ASCRAs still remain common in the United Kingdom, in the form of Christmas clubs and other savings clubs, while Credit Unions are expanding.

But Geertz was wrong, as I said at the time, in thinking that everywhere the ROSCA would fade away. In Africa - and elsewhere, including among immigrants in the USA (as Bridget's case exemplifies) - ROSCAs are, if anything, proliferating. A friend of 
mine in the UK has been a professional financial adviser, and property owner, yet he still belongs to his ROSCA back in the village, as a sign of solidarity and of shared belonging with his neighbours at home. For a while he was a member of an ASCRA in the UK (which I attended); it was composed of fellow "elite" Cameroonians (including doctors, accountants, computer experts), but differences of opinion in investment policy led him to resign, and go it more alone. This is the problem with ASCRAs, they need a high quality of leadership and, especially, a common understanding, such as the Kenyan women were given by the charismatic Mama Alice - not to speak of her contacts (Nelson, 1995). Wright (2008) has documented an opposite case - the demise of an ASCRA in Peru which failed because of favouritism of the officer, despite, or perhaps because of, her contacts: she gave all the loans to her friends.

We have seen that groups, such as school friends, often continue their cycles for decades. As they advance in life, their dues are likely to go up, and their "picks" become bigger. If some of the members become more affluent than others, they will form a new high-value group which runs in parallel with their original group - and belong to both, for to abandon their less prosperous friends would be frowned upon.

Trust is important then. In Cameroon, traditional beliefs in witchcraft or sorcery are not forgotten. One particular form of witchcraft found among the coastal people of Cameroon, called nyongo, was associated with unwittingly touching (charmed) money, from which bewitchment followed. This belief was widespread when we first went to Cameroon. My husband wrote a paper in 1970 about it, entitled "Witchcraft, Economics and the Continuity of Belief" (in Douglas, 1970, reprinted in Ardener, The Voice of Prophesy). He showed how preoccupation with this sort of witchcraft rose when times were bad, and fell away when the economy flourished. At the time, personal economic success not shared was considered to be incompatible with family and community acceptability. In the past, traditional ceremonies (for example Eyu among the Bakweri of Cameroon) could be performed by successful men, whereby wealth - then mainly in the form of livestock - was redistributed (see Ardener 1956). In return for their generosity they received high moral regard. Such men were the equivalent of the big benefactors who founded the Oxford colleges and of contemporary philanthropists like Bill Gates.

Under colonialism, modern opportunities, open only to the few, introduced new inequalities and disrupted the former village harmony to a certain extent. People became suspicious of others who were wealthier than their fellows for no very apparent reasons, especially if members of their families died unexpectedly. Men who suddenly prospered became at risk of being regarded as nyongo witches, who seemed to kill their kin, while in fact the kin became the un-dead - working unseen on the known, but mystical, Mount Kupe, creating wealth for the big men (Ardener, in Douglas 1970; reprinted Ardener, I996, p. 4Iff). Such traditional beliefs, in the context of money, were one reason why members used to scrutinise potential newcomers so carefully. This also accounts for why, in some groups in Cameroon, members drink from the same pot of raffia wine (Ian Fowler, personal communication).

Given this background, it is interesting that five or so years ago, already a time of 
economic retrenchment, I was told by a senior colleague at a university in Cameroon that one member of her village ROSCA had had a number of near death accidents, and had consulted a diviner, who told her that one of the ROSCA members was practising nyongo against her. This led to the failure of the ROSCA. When I was preparing this paper I asked among my friends; several told me they had heard stories that such people existed in other places, among other Cameroon tribes.

Environmental catastrophes can also impinge on microfinance activity and on money transferring. It was reported in the Financial Times that, following the recent earthquake in Haiti, the main banks immediately closed their vaults while 42 offices (that's about half) of the dominant microfinance agency (Fonkoze), which transfers remittances from the US, remained open. Said by the World Bank to be worth $\$ 1.2$ billion in 2008 , it is forecast that remittances to Haiti will double in 2010 (Rappeport and Mander, Financial Times, 2r January, 20ro).

Likewise, war is disruptive. The current Somali conflict, which Anna Lindley examines, is most extreme. The role of London-based ROSCAs (with largely female membership) in supporting war in Somalia was documented by Hazel Summerfield in Money-GoRounds fifteen years ago. Lindley (2009, p. 520) recently writes that "there is now great interest in how extra-state economic activities, often with a significant global reach, become part of the endogamous dynamics that protract conflict in Africa". She talks of the "fundamental ambivalence of the international community" towards the informal shadow economies in Africa (Lindley, quoting Mark Duffield, 2002). Yet in the chaos of war, and the breakdown of infrastructure, Somalians continue to operate extensive networks of money transmitting businesses, with over one thousand branches, employing thousands of employees and agents. Unsurprisingly, the USA became suspicious that these operations were aiding terrorists, and in $200 \mathrm{r}$ intervened to close the largest down. European governments have been less paranoid about them.

ROSCAs are known for their flexibility, which gives them ways of coping with financial fluctuations. Cycles are often kept short (frequently lasting for just one year) so that, when the cycle restarts, dues can be adjusted downward (in hard times) or upwards (as members become more affluent). A ROSCA can also quickly adjust to hard times by spacing out times for paying dues - say by collecting them monthly instead of weekly, or by suspending them over Christmastide.

Because "picks" can lose or gain value through price fluctuations and inflation, ROSCA dues can be tied to the cost of a commodity, such as a gold coin (Cyprus, see KhatibChahidi 1995), or the price of a zinc roofing sheet (Indonesia, see Hospes 1995).

As for today, the current credit crunch is a more than usually dramatic an event. Due to this, Stiglitz notes a possible intellectual crisis of confidence in formal Western-style banking, and for American-style capitalism (Stiglitz, quoted in Cramer et al., 2009, p. 653). An even more pessimistic view of the flow of money between Africa and overseas, over the past four decades, was given by David Smith (in Guardian .co.uk on April I ${ }^{\text {rst }}$ 20I0). He suggested that during this period, Africa may have lost more than fitn (tn=trillion) in illegal flows of money which have gone into western financial institutions, due to false 
pricing, tax evasion, etc. This, if true, vastly exceeds official accounts of inflows to Africa.

Yet countries have coped with financial calamities before today. When all economic activity in Taiwan was in financial shock, ROSCA participation dropped from 1983 to its low in 1985 . In their 1993 paper, Besley and Levenson provide graphic representation of the slide; they do not go into any detail, but report how confidence was soon restored and ROSCAs quickly rose to near their earlier levels. Also the IMF view of recent events is somewhat optimistic: it discounts the direct impact of the world financial markets crisis on many sub-Saharan economies, stating that they are only weakly integrated in global markets (see Cramer et al., 2009, p.647). In Lesotho, remittances account for $30 \%$ of its GDP. Senegal, where recorded remittances have increased dramatically over the last five years, and which now represent $\mathrm{II} \%$ of its GDP, is likewise seen to be relatively unaffected by the financial crisis. And remittances from overseas to Nigeria are said to have weathered better than elsewhere. Moreover, it is thought that China and India, which are doing better than many other countries, are likely to continue their economic support for Africa.

However, the world recession could have some impact on aid and on remittances home. Certainly, my Cameroon friends are aware of the problem, and they assure me that, in these troubled days of credit crunch, people cling even more strongly to their various savings clubs than before. Professor Fanso told me in January 2010 that recently people have become particularly sensitive to risk, and financial instability. He reported that the practice in a ROSCA in Cameroon now is that, besides having a compulsory subscription to an interest-paying loan box (the RESCA), there is another separate fund (an ASCRA) to which members may voluntarily subscribe - when and as much as they wish. An account is kept of each member's contribution to the ASCRA; this money can be drawn on by the subscriber in times of sudden financial need. So we have, in effect an ASCRA nesting inside a RESCA, inside a ROSCA. In other words, this ASCRA is a proto-bank. As noted above, to make this system sustainable requires a considerable degree of mutual trust and transparent accounting.

Let us finally return to Bridget and her efforts to assist her people. Her case may not be typical; she is a model of prudence not all can emulate. Living costs are high and many have large families to support. But Bridget's case does highlight the role ROSCAs play in remittances sent home to the developing world. I understand the flow of aid returning from the African diaspora now outstrips the formal aid from Western governments and NGOs. The proliferation of formal money transfer offices in small towns in Cameroon is a recent sign of this flow. Mobile phone messages certainly speed up flows from money businesses overseas to Cameroon, and visa versa. The transferring of money between mobile telephones is said to be rapidly expanding in parts of Africa; their role in direct money exchanges in Cameroon has yet to be assessed. Reinvesting money back home often proves difficult for immigrants. Their cash has, however, significantly improved housing, health and educational standards. ROSCAs still play a role in this. ROSCAs are alive and kicking! 


\section{Acknowledgements}

I am indebted to the University of Gent for inviting me to be the Annual Distinguished Lecturer at their GAP Symposium (GAPSYM3) Gendering Research in/on Africa, held on 18 th December 2009, where I met many distinguished scholars. The occasion will be remembered for its vitality, and for the spectacular fall of snow which lit up the city. Of others who helped me, I am particularly grateful to Dr Bridget Teboh for enriching my paper with the information she generously gave me on her own savings practices.

\section{References}

Ardener, E.W. (1970). Witchcraft, Economics and the Continuity of Belief. In: Douglas, M. (ed.). Witchcraft Confessions and Accusations, London: Tavistock, I4I-1960.

Ardener, Shirley (1953). The Social and Economic Significance of the Contribution Club in a Section of the Southern Igbo. Conference Proceedings, West African Institute of Social and Economic Research, Ibadan, I28-42.

- (1964). The Comparative Study of Rotating Credit Associations. Journal of the Royal Anthropological Institute, 94 (2), reprinted in Ardener \& Burman, 201-229.

- (1995). Women Making Money Go Round; ROSCAs Revisited. In: Ardener \& Burman, I-I9.

Ardener, Shirley \& Sandra Burman, (eds.), (1995). Money-Go-Rounds: The Importance of ROSCAs for Women. Oxford and Washington: Berg, 327.

Bai Senghor, S. (2008). The Emergent Role of Central Banks in Addressing Rural Finance Challenges; the Gambia Experience. Paper presented during Africa's Technical Workshop on Innovations in Addressing Rural Finance Challenges in Africa, Dar es Salaam, Tanzania, 2008, 14.

Besley T., \& A. Levenson (1993). The Role of Informal Finance in Household Capital Accumulation: Evidence from Taiwan. Discussion Paper, Woodrow Wilson School of Public and International Affairs, Princeton.

Bryceson, Deborah, Judith Okely et al. (2007). Identity and Networks; Fashioning Gender and Ethnicity Across Cultures. Oxford \& New York: Berghahn Books, 302.

Burman, Sandra \& Nozipho Lembete (1995). Building New Realities: African Women and ROSCAs in Urban South Africa. In: Ardener and Burman (eds.) 1995, 23-47.

Cramer, Christopher, Deborah Johnston and Carlos Oya (2009). Africa and the Credit Crunch: from Crisis to Opportunity? In: African Affairs, 108/433, 653-654.

Douglas, Mary, (1970). Witchcraft, Confessions and Accusations. London: Tavistock.

Fonchingong, Charles (2008). Gender Dynamics of Elderly Welfare and Semi-formal Protection in Cameroon. Chapter 9, doctoral thesis, University of Buea, Cameroon.

Hospes, Otto (1995). Women's Differential Use of ROSCAs in Indonesia. In: Ardener \& Burman 1995, 127-248.

Khatib-Chahidi, Jane (1995), Gold Coin and Coffee ROSCAs; Coping with Inflation the Turkish Way in Northern Cyprus. In: Ardener and Burman (eds.), 241-26r.

Levenson, Alec \& Timothy Besley (1996). The Anatomy of an Informal Financial Market: ROSCA Participation in Taiwan. In: Journal of Development Economics, 51, 1996.

Lindley, Anna (2009). Between 'Dirty Money' and 'Development Capital'; Somali Money Transfer Infrastructure under Global Scrutiny. In: African Affairs, 108/433, 519-539.

Nelson, Nici (1995). The Kiambu Group: A Successful Women's ROSCA in Mathare Valley, Nairobi (1971 to 1990). In: Ardener and Burman (eds.), 49-69.

Niger-Thomas, Margaret (1995). Women's Access to and the Control of Credit in Cameroon: the Mamfe Case. In Ardener \& Burman (eds.) 1995, 95-124.

Rappeport, Alan \& B. Mander (2010). Haiti: Obstacles sever diaspora's lifeline, in The Financial Times, January, 2010, p.ro. 
Rowlands, Michael (1995). Looking at Financial Landscapes: a Contextual Analysis of ROSCAs in Cameroon. In Ardener \& Burman (eds.) III-I24.

Shrinivasan, Shaila (1995). ROSCAs among South Asians in Oxford. In: Ardener and Burman (eds.) 1995, pp. 199-208.

Summerfield, Hazel (1995). A Note on ROSCAs among Northern Somali Women in the United Kingdom. In Ardener and Burman (eds.) 1995, 209-215.

Wright, Katie (2008). The Darker Side of Microfinance: Evidence from Cajamarca, Peru. Personal communication, pp.15.

Verhoef, Grietii (1999). Stokfels and Economic Empowerment: the case of African Women in South Africa, 1920-1996. Paper given at a conference on Women and Credit: Past Practice, Present Priorities, 1600-2000, New Brunswick, Canada, 1999. 